\title{
Effect of Yeast Based Biofertilizer combined with bacteria on Mustard Plant Growth
}

\author{
Nur Hidayatul Alami, Silviya Amaliya Trisna Ayu, Nengah Dwianita Kuswytasari, Enny \\ Zulaika, and Maya Shovitri
}

Department of Biology, Institut Teknologi Sepuluh Nopember, Surabaya, Indonesia

\begin{abstract}
Biofertilizers are commonly defined as microbial inoculants which are capable of mobilizing important nutrient in the soil from non-available to available form for the plants through their biological processes. Hence to increase the productivity of the soil, the use of biofertilizer is necessary. Candida yeast as a phosphate solubilizer and decomposer. Azotobacter bacteria as a nitrogen-fixing bacteria and Bacillus as a phosphate solubilizer. The combination of these microorganisms as biofertilizer needs to be tested its effect against mustard (Brassica juncea L.) plant growth.The results showed that the combination of Bacillus Candida obtained the highest yield among other biofertilizer treatments with a value of $13.6 \mathrm{~cm}$ at plant height, 4.96 grams in wet weight and 2.29 grams in dry weight. The combination of Azotobacter Candida showed the highest result on the parameter of width and number of leaves with the values of $20.3 \mathrm{~cm}$ and 5.3 . Combination of Azotobacter Bacillus Candida showed the highest yield on the root length parameter with a value of $5.0 \mathrm{~cm}$. The addition of biofertilizer is expected to reduce pollution on the soil due to residues produced by chemical fertilizers.
\end{abstract}

\section{Article History}

Received 21 November 2017

Accepted 29 December 2017

Keyword

Azotobacter

Bacillus

Biofertilizer

Candida

Mustard Plant

\section{Introduction}

Biofertilizer application to overcome the problem of land degradation due to the use of chemical fertilizers has been the focus of the study until the last few decades. Compared with chemical fertilizers, biofertilizers are shown to have a better ability to increase crop productivity because biofertilizers are enriched by microorganisms and plant growth promoters with a beneficial consortium of microorganisms (Paszt et al., 2015). The biofertilizer-consortia microorganisms may include groups of fungi, bacteria, or protozoans (Cavalier-Smith, 1998; Lucy et al., 2004; Smith and Read, 2008; Vessey, 2003) which, when applied, can increase the availability of nutrients from biological activity and can improve soil quality. Biofertilizer is able to provide elements of $\mathrm{N}, \mathrm{P}$ and $\mathrm{K}$ as well as nutrients for plants that can affect the growth and productivity of plants (Agamy et al., 2013).

Study on the production of biofertilizers using bacteria and yeast has been widely used, Wani et al. (2013) state that Azotobacter bacteria are able to fix $10 \mathrm{mg}$ of nitrogen from 
one-tenth of carbon sources conducted in vitro (Amprayn et al., 2012). This study uses a consortium of Candida yeast and Azotobacter and Bacillus bacteria. Some Candida species are able to solubilize phosphate and degrade organic compounds, Azotobacter is a siderophore bacteria and capable of fixing nitrogen, and Bacillus is able to dissolve phosphate in the soil (Xiao et al., 2013; New et al., 2013; Fleet, 1992; Ali and Vidhale, 2013; Maheswar and Sathiyavani, 2012). Biofertilizers use the molasses carrier as the main carbon source for the growth of the isolates. Molasses were selected because of their effectiveness and efficiency as carriers for controlling microbial growth.

Plants that have the potential to be used as research object is the mustard plant (Brassica juncea L.). Mustard is an annual plant that can grow in lowland to upland (Devi et al., 2017), able to grow and adapt well to almost all soil types, have a short harvest age (35 days), and leaves are used by Indonesian people as vegetables because of high nutritional value. Based on the ability of microorganisms, it is necessary to study more about the effect of the combination of yeast and bacteria as biofertilizer on mustard plant growth.

\section{Materials and Methods}

Isolates

Isolates used in this research were Candida W3.8 and Candida G3.2 and isolates of Azotobacter A10 and Bacillus spp., collection of Microbiology and Biotechnology Laboratory, Biology Department, Institut Teknologi Sepuluh Nopember Surabaya (ITS).

\section{Preparation of Microbial Suspension}

Measurements of yeast and bacteria growth were done by adding each culture in $0.85 \%(\mathrm{w} / \mathrm{v})$ of physiological solution, consisting of $\mathrm{NaCl}$ and aquades. Absorbance was measured using a UV-Vis spectrophotometer with OD 0.5 at $\lambda 600$ for yeast and OD 0.5 at $\lambda$ 620 for bacteria. The value of OD is based on the approximate number of yeast and bacterial cell densities (about $10^{7} \mathrm{CFU} / \mathrm{ml}$ ).

\section{Growth of Yeast and Bacteria in Molasses Medium}

About $10 \%$ of microbial suspension from the previous step then inoculated into molasses production medium and CzapekDox. Molasses is a carrier medium which has been known as microbial growth substrate. CzapekDox Broth ( $\mathrm{g} / \mathrm{L}$ ) consisting of sodium nitrate ( 3 $\mathrm{g})$; Dipotassium phosphate $(1 \mathrm{~g})$; Magnesium sulphate $(0.5 \mathrm{~g})$; Potassium chloride (0.5); Ferrous sulphate $\left(\mathrm{FeSO}_{4}\right),(0.01 \mathrm{~g})$; Aquadest $\left(\mathrm{H}_{2} \mathrm{O}\right)(1000 \mathrm{~mL})$. The volumes of the inoculum was added to the carrier medium based on the different treatment groups (Table 1.)

Table 1. Volumes of Inoculum

\begin{tabular}{|c|c|}
\hline Treatment & Suspension Volume \\
\hline Treatment 1 : & $\begin{array}{l}5 \mathrm{ml} \text { of Candida W2.8 }+5 \mathrm{ml} \text { of Candida } \mathrm{G} 3.2+90 \mathrm{ml} \text { of molasses and Czapek } \\
\text { Dox }\end{array}$ \\
\hline Treatment 2 : & $10 \mathrm{ml}$ of Azotobacter A10 + $90 \mathrm{ml}$ of molasses and Czapek Dox \\
\hline Treatment 3 : & $10 \mathrm{ml}$ of Bacillus spp. $+90 \mathrm{ml}$ of molasses and Czapek Dox \\
\hline Treatment $4:$ & $\begin{array}{l}3,3 \mathrm{ml} \text { of Candida W2.8 }+3,3 \mathrm{ml} \text { of Candida } \mathrm{G} 3.2+3,3 \mathrm{ml} \text { of Azotobacter A10 + } \\
90 \mathrm{ml} \text { of molasses and Czapek Dox }\end{array}$ \\
\hline Treatment 5 & $\begin{array}{l}\text { 3,3 } \mathrm{ml} \text { of Candida W2.8 }+3,3 \mathrm{ml} \text { of Candida } \mathrm{G} 3.2+3,3 \mathrm{ml} \text { of Bacillus spp. }+90 \\
\mathrm{ml} \text { of molasses and Czapek Dox }\end{array}$ \\
\hline Treatment $6:$ & $\begin{array}{l}2,5 \mathrm{ml} \text { of Candida W2.8 }+2,5 \mathrm{ml} \text { of Candida } \mathrm{G} 3.2+2,5 \mathrm{ml} \text { of Azotobacter A10 + } \\
2,5 \mathrm{ml} \text { of Bacillus spp. }+90 \mathrm{ml} \text { of molasses and Czapek Dox }\end{array}$ \\
\hline
\end{tabular}


Each combination of biofertilizer was homogenized on a rotary shaker for 7 days (Anubrata and Rajendra, 2014). Measurement of growth was done daily with Total Plate Count method to obtain maximum growth day. The best incubation time to be used for biofertilizer production was based on the total number of inoculums of $10^{9} \mathrm{CFU} / \mathrm{mL}$ (Noel et.al., 2016) in each treatment group.

\section{Planting and Maintenance of Mustard}

Mustard seeds were soaked with water for 24 hours, then seeds that were submerged in water were selected. Seeds were allowed to grow in seedling medium at least until two leaves were formed or 14 days after planting. Application of biofertilizer was done in 2 stages, the first given at 14 days before the seed was transferred to planting medium, and the second at 14 days after planting. Biofertilizer is composted by watering $250 \mathrm{ml}$ into polybags. Plants are grown for 4 weeks. Measurements of growth include plant height, leaf area, number of leaves, root length and biomass (dry weight).

\section{Plant Height Measurement}

Plant height is measured from ground level to the highest leaf. Plant height measurement was done once a week for 5 weeks.

\section{Measurement of Leaf Area}

The leaf area is calculated by millimeter paper method by putting the leaves on millimeter paper and leaf pattern followed. The leaf area is estimated based on the number of squares contained in the leaf pattern. The measurement of leaf area is done once a week for 5 weeks.

\section{Number of Leaf Calculation}

The number of leaf calculation was done on leaves that had developed perfectly. Counting the number of leaves were done once a week for 5 weeks.

\section{Root Length Measurement}

The measurement of root length with destruction method was done by removing the whole plant and measuring the root length from root base to root tip by using ruler. Root length measurements were made at harvest time.

\section{Biomass Calculation}

Biomass is obtained from the dry weight of the plant. Before weighing the plant is cleaned with water and dried wind. The dry weight of the plant was carried out by drying at $60^{\circ} \mathrm{C}$ for 4 days, then was weighed using analytical balance. Biomass measurements were made during harvest time.

\section{Research Design}

The design of this study used a completely randomized design with 6 treatments for 5 weeks and 3 repetitions. Research design are shown in the figure 1. 


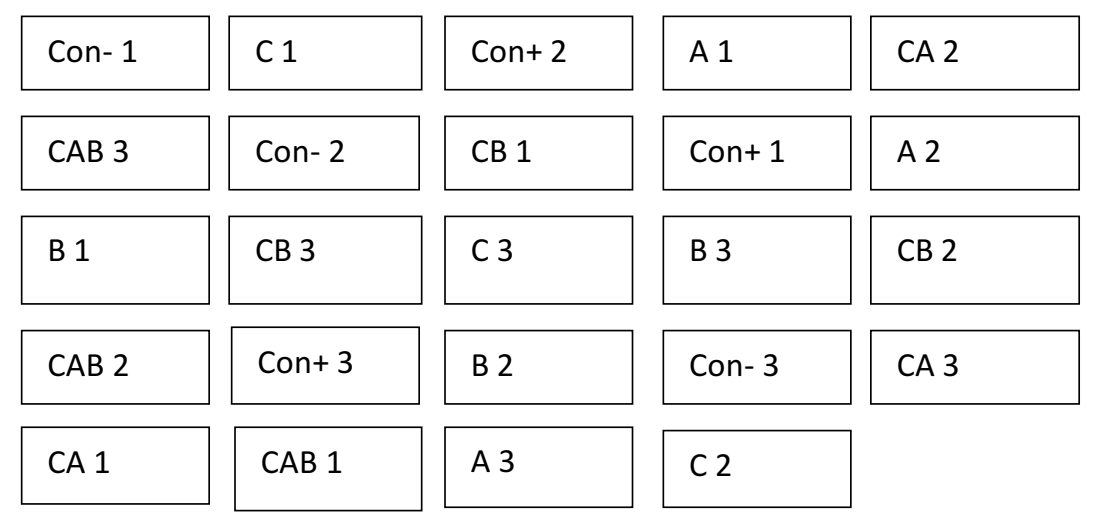

Figure 1. Research Design, Con-1: Negative control repetition 1; C1: Biofertilizer of Candida repetition 1; Con+ 2: Positive control repetition 2; A1:Biofertilizer of Azotobacter repetition 1; CA2: Biofertilizer of Candida and Azotobacter repetition 2; CAB3: Biofertilizer of Candida, Azotobacter, and Bacillus repetition 3; Con-2: Negative control repetition 2; CB1: Biofertilizer of Candida and Bacillus repetition 1; Con+1: Positive control repetition 1; A2: Biofertilizer of Azotobacter repetition 2; B1: Biofertilizer of Bacillus repetition 1; CB3: Biofertilizer of Candida and Bacillus repetition 3; C3: Biofertilizer of Candida repetition 3; B3: Biofertilizer of Bacillus repetition 3; CB2: Biofertilizer of Candida and Bacillus repetition 2; CAB2: Biofertilizer of Candida, Azotobacter, and Bacillus repetition 2; Con+3: Positive control repetition 3; B2: Biofertilizer of Bacillus repetition 2; Con-3: Negative control repetition 3; CA3: Biofertilizer of Candida and Azotobacter repetition 3; CA1: Biofertilizer of Candida and Azotobacter repetition 1; CAB1: Biofertilizer of Candida, Azotobacter, and Bacillus repetition 1; A3: Biofertilizer of Azotobacter repetition 3; C2: Biofertilizer of Candida repetition 2.

Data Analysis

The data analysis used ANOVA-One Way for combination of yeast and bacteria as biofertilizer against plant growth.

\section{Results and discussion}

The preparation of biofertilizer should consider the substance of carrier media and biological agents. Carrier media should also contain an important component to support the viability and growth of inoculated microbes. One of the carrier media for the biofertilizer is molasses which have been known as the microbial growth substrate. Molasses were selected because of their effectiveness and efficiency as carriers for the growth of biofertilizer agent. Molasses can be used as an alternative substrate because it contains complex nutrients that was taken by microbes for metabolism process, it contains not less than $46 \%$ total sugars (Duraisam et al., 2017), including a water content, nitrogen and minerals that are used for microbial growth.

Molasses used in this research is a source of carbon (C) for the microorganism, molasses can be combined with the medium Czapekdox broth, with a composition of Sodium nitrate $\left(\mathrm{NaNO}_{3}\right)$ as a source of protein, Dipotassium phosphate $\left(\mathrm{KH}_{2} \mathrm{PO}_{4}\right)$, Magnesium sulphate $\left(\mathrm{MgSO}_{4} \cdot 7 \mathrm{H}_{2} \mathrm{O}\right)$, Potassium chloride $(\mathrm{KCl})$, and Ferrous sulphate $\left(\mathrm{FeSO}_{4}\right)$ which is a source of salts and minerals for the growth of biofertilizer agent. Carrier media with the 
content of organic and mineral are expected to make the microorganisms can compete with microorganisms in the soil. Thus able to dominate around plant roots.

The biofertilizer should be contain the minimum population of the total bacteria of $\geq$ $10^{9} \mathrm{cfu} / \mathrm{ml}$ or 9 log cfu / $\mathrm{ml}$ for the positive influence of microbes in the biofertilizer (Masso et al., 2015). Therefore, the consortium formulation of biological agents and carrier media is necessary to enhance plant growth and productivity.

The Calculation of microorganism was performed before the biofertilizer was applied to mustard for 7 days. Observations started from day 0 of inoculation to day 7 of the incubation period. The microbial growth results are shown in Figure 2.

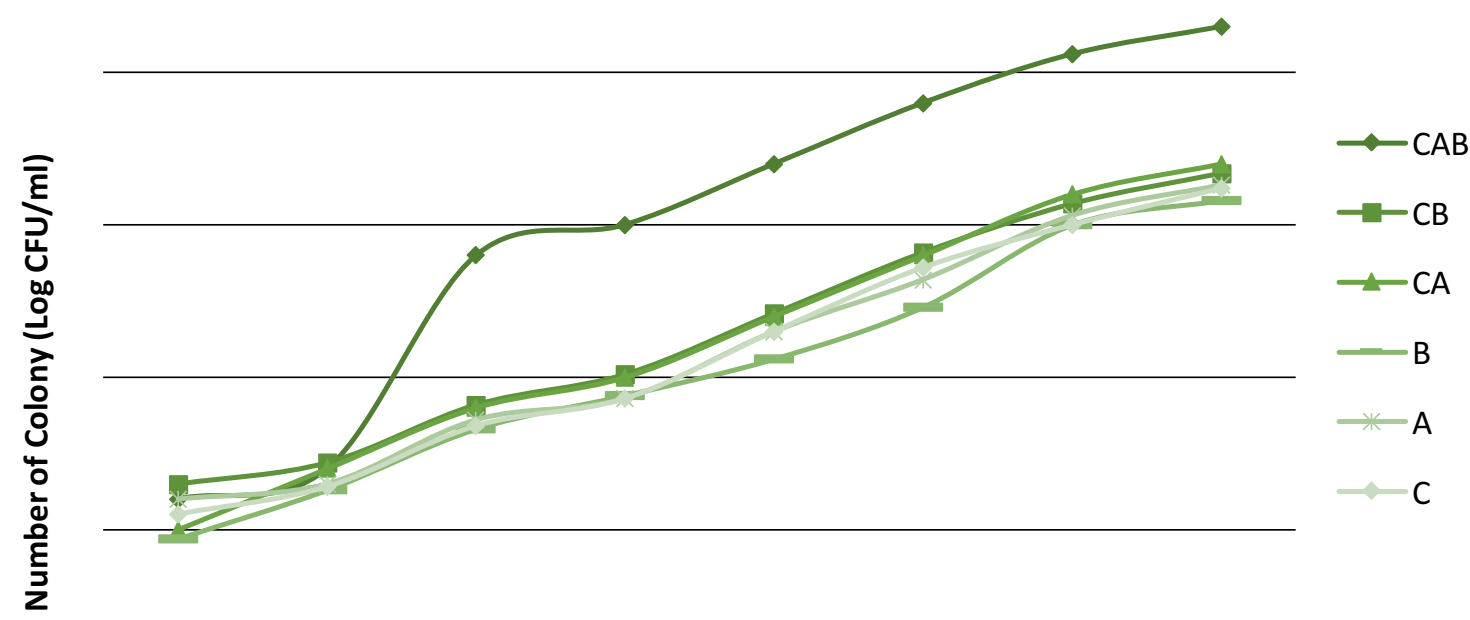

Day

Figure 2. Growth of Yeast and Bacteria Consortium on Molasses Medium

Figure 1 shows that the growth increased gradually until the 7 days of incubation time. This suggests that yeast and bacterial of biofertilizer was able to increase in numbers during the application of the soil so that the microbes in the biofertilizer potentially increasing nutrient uptake by plants .

The increase in the population of consortium in a test of viability indicates that the agent biofertilizer used consisting of a single colony which include yeast candida, bacteria Azotobacter and Bacillus, a consortium of the yeast Candida and Azotobacter, yeast Candida and Bacillus, as well as a consortium of yeast Candida, Azotobacter and Bacillus able to grow. On day 0 shows an indication of metabolic activity performed by all inoculants. Yeasts and bacteria utilize nutrients in the medium for growth. According to (Brock, 1991), in the adaptation phase, an increase in cell size, the cell does not divide or slightly division. This condition, characterized by an increase in the macromolecular components, metabolic activity, and the number of cells that slowly began to increase.

In all treatments on the first day until the seventh day there is an increase in the number of cells. This is because Yeast and bacteria are in the logarithmic phase. Cells will continue to multiply by utilizing molasses as the main source of nutrients. According to (Paulton, 1991) In the exponential or logarithmic phase, the period and volume of cells increase and and the speed of increase can be expressed with exponential function. 
The results of plant height measurements of the mustard are shown in Figure 3. In Figure 3 it shows that plant height increased every week during the planting time up to 28 days after planting. The increasing of plant height can be affected by the availability of various nutrients on the soil that has been provided by biofertilizer. One-way ANOVA results of the week 4 (harvest time) show that probability value is less than 0.05 ie 0.001 , so the biofertilizer gives effect to the height of the mustard so that Tukey test was done at $95 \%(\alpha=0,05)$ using Minitab software. Tukey test results are shown in Table 2.

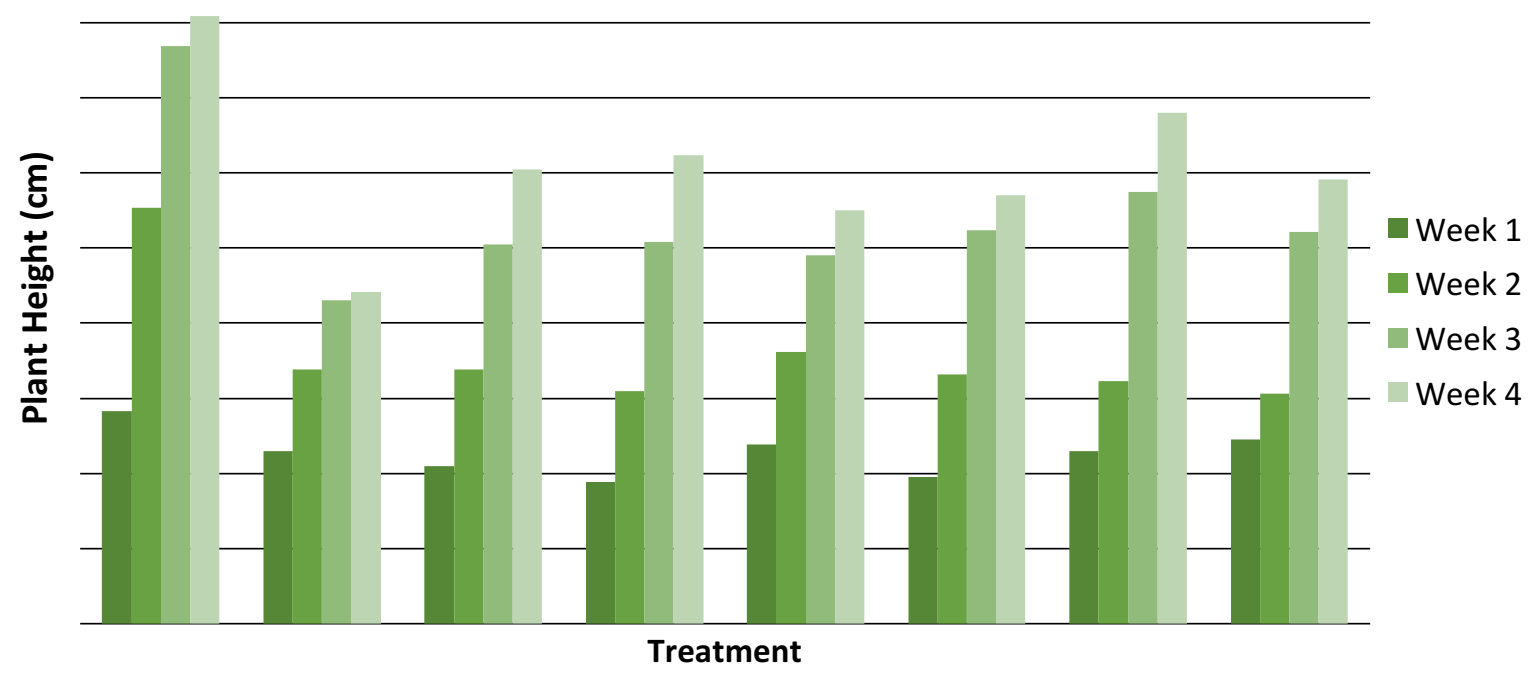

Figure 3. Result of Plant Height

Table 2. Height of mustard plants at harvest time

\begin{tabular}{lc}
\hline \multicolumn{1}{c}{ Treatment } & Plant high (cm) \\
\hline Positive control & $16,167^{\mathrm{a}}$ \\
Bacillus Candida & $13,600^{\mathrm{ab}}$ \\
Bacillus & $12,467^{\mathrm{abc}}$ \\
Azotobacter & $12,100^{\mathrm{abc}}$ \\
Azotobacter Bacillus Candida & $11,833^{\mathrm{bc}}$ \\
Azotobacter Candida & $11,400^{\mathrm{bc}}$ \\
Candida & $11,000^{\mathrm{bc}}$ \\
Negative control & $8,833^{\mathrm{c}}$ \\
\hline
\end{tabular}

*Figures followed by different letters show significant differences based on the Tukey test at the $95 \%$ confidence level $(\alpha=0.05)$.

Based on Table 2 it can be seen that the influence of biofertilizer on the height of the mustard in Bacillus Candida treatment has the highest effect when compared with the treatment of the addition of another biofertilizer. Bacillus is able to synthesize growth hormone IAA, gibberellins and cytokinins (Park et al., 2017), and dissolves phosphates that are not available in the soil by the mechanism of organic acid secretion. Phosphate is an important macronutrient for plants for high plant growth (Wang et al., 2011) The ability of Bacillus is combined with Candida which has the potential to dissolve organic and inorganic phosphate, acting as a bio-activator for the breakdown of organic matter that will contribute nutrient supply for soil to plant height . 
Plant height in positive control is highest because the positive control (NPK fertilizer) contains nutrients and minerals that can be utilized directly by plants, so the plant can take the nutrition quickly. Mustard plants have a short harvest age, thus the available uptake of nutrients is also fast. But the continued use of chemical fertilizers can leave residues thereby destroying soil and the environment. Treatment of negative control has the lowest effect on the high of mustard. This is because the negative controls in this study only use soil as a planting medium without any addition of fertilizers in which contain more nutrients needed for plant growth height, so the roots will only absorb the macro and micro essential elements available in the soil.

The results of the measurements of the leaf number and leaves area are shown in Figure. 4 and 5. The leaf number and leaves area has increased each week. The result of oneway ANOVA showed that the probability value of the area and the number of leaves was less than 0.05 ie 0.003 and 0.000 respectively so that the biofertilizer had an effect on the leaf area and number, so that The Tukey test was done at $95 \%(\alpha=0.05)$ By using Minitab software. Tukey test results are shown in Table 3.

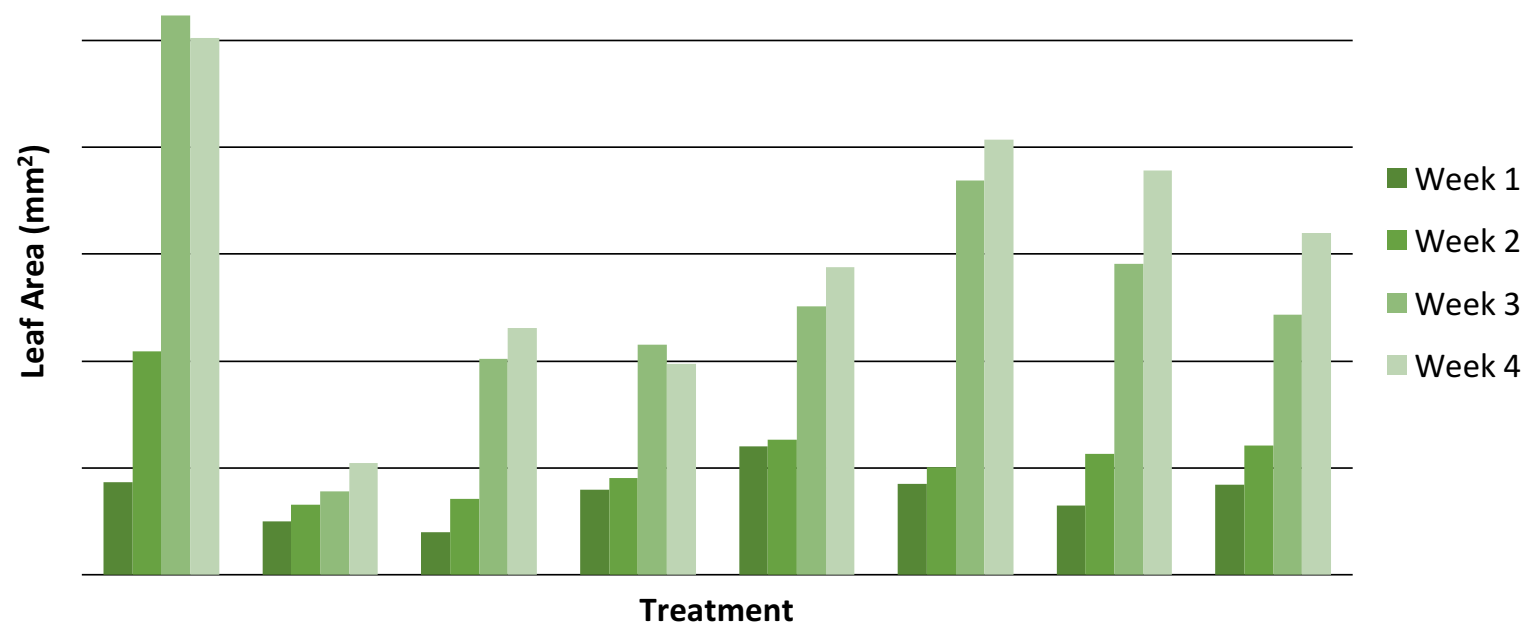

Figure 4. Result of Leaf Area

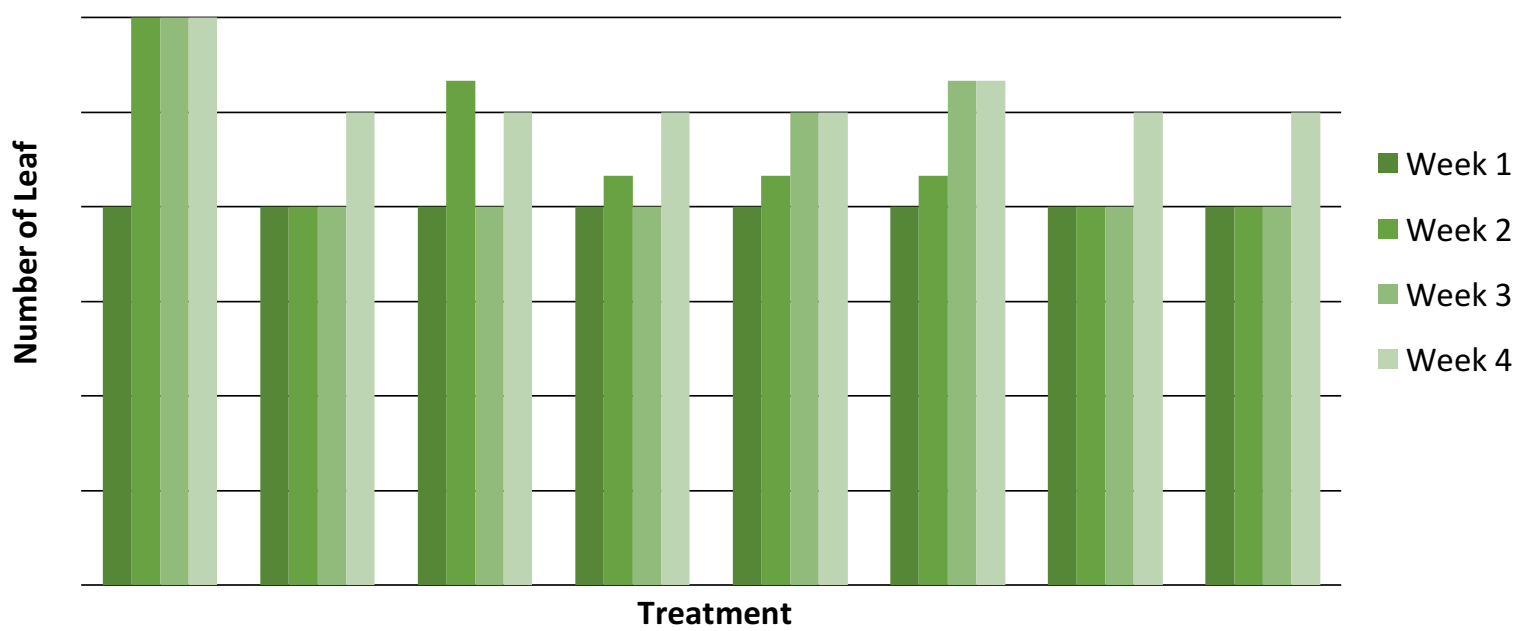

Figure 5. Result of Leaf Number 
Table 3. Leaf Area and Number of Leaf at Harvest Time

\begin{tabular}{lcc}
\hline \multicolumn{1}{c}{ Treatment } & Leaf Area $(\mathrm{cm})$ & Number of Leaf \\
\hline Positive Control & $25,100^{\mathrm{a}}$ & $6^{\mathrm{a}}$ \\
Azotobacter Candida & $20,300^{\mathrm{ab}}$ & $5,3^{\mathrm{b}}$ \\
Bacillus Candida & $18,867^{\mathrm{ab}}$ & $5,0^{\mathrm{b}}$ \\
Azotobacter Bacillus Candida & $15,967^{\mathrm{abc}}$ & $5,0^{\mathrm{b}}$ \\
Candida & $14,333^{\mathrm{abc}}$ & $5,0^{\mathrm{b}}$ \\
Azotobacter & $11,533^{\mathrm{bc}}$ & $5,0^{\mathrm{b}}$ \\
Bacillus & $9,867^{\mathrm{bc}}$ & $5,0^{\mathrm{b}}$ \\
Negative Control & $5,167^{\mathrm{c}}$ & $5,0^{\mathrm{b}}$ \\
\hline
\end{tabular}

*Figures followed by different letters show significant differences based on the Tukey test at the $95 \%$ confidence level $(\alpha=0.05)$.

Based on Table 3 it can be seen on the biofertilizer treatment of Azotobacter and Candida consortium showed the highest yield. The most needed nutrient in the leaf area and the number of leaves is the Nitrogen (Ng'etich, 2013). The potential of Azotobacter in nitrogen fixation is combined with Candida in dissolving phosphate into the forms available for plants. This is consistent with (Plaster, 2003) that nitrogen is more necessary in support of vegetative growth than generative and important for vegetable crops consumed by the canopy.

The positive control has the highest result, this is the same as the previous parameter indicating positive control treatment has the highest value. This is because the chemical fertilizer (NPK fertilizer) provided an inorganic nitrogen element that is ready for use for leaf area and the number of leaves. In the negative control showed the lowest result. This is in accordance with soil nitrogen content test results indicating that the nitrogen content in the soil with the addition of NPK fertilizer amounted to $0.21 \%$, in the addition of biofertilizer of $0.14 \%$ and the media of garden soil only $0.02 \%$.

Root length measurement results are shown in Figure 6. Based on figure 6 it can be seen that the positive control effect on long root growth with the highest value when compared with treatment of biofertilizer and negative control. One-way ANOVA results show that the probability value is less than 0.05 , so the biofertilizer gives effect to the root length of the mustard so that The Tukey test was done at 95\% ( $\alpha=0.05)$ By using Minitab software. Tukey test results are shown in Table 4.

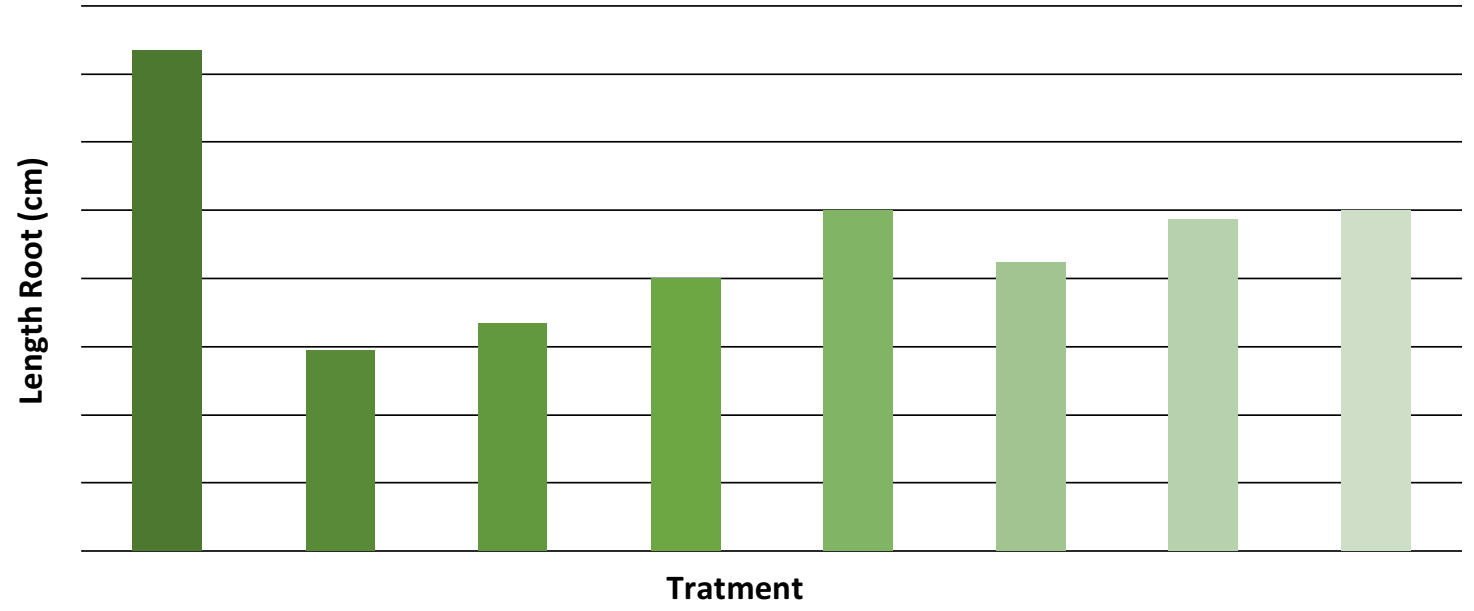

Figure 6. Result of Root Length 
Table 4. Root Length at Harvest Time

\begin{tabular}{lc}
\hline \multicolumn{1}{c}{ Treatment } & Root length (cm) \\
\hline Positive Control & $7,333^{\mathrm{a}}$ \\
Azotobacter Bacillus Candida & $5,000^{\mathrm{ab}}$ \\
Candida & $5,000^{\mathrm{ab}}$ \\
Bacillus Candida & $4,867^{\mathrm{ab}}$ \\
Azotobacter Candida & $4,233^{\mathrm{ab}}$ \\
Bacillus & $4,000^{\mathrm{ab}}$ \\
Azotobacter & $3,333^{\mathrm{b}}$ \\
Negative Control & $2,933^{\mathrm{b}}$ \\
\hline
\end{tabular}

*Figures followed by different letters show significant differences based on the Tukey test at the $95 \%$ confidence level $(\alpha=0.05)$.

Based on Table 4 it can be seen on the biofertilizer treatment of Azotobacter Bacillus Candida consortium and single culture Candida showed the highest result. Candida is able to decompose the organic compounds in the soil and phosphate solubilizer, Azotobacter potential for nitrogen fixation and also have siderophores, are complexing or specific compounds of chelating Fe $3+$ or iron to bind elemental iron in the rhizosphere, so it is not available for the development of pathogenic microbes. Bacillus sp., potential as a phosphate solubilizer and root biological controller. It is also appropriate with the test results of the phosphate (P2O5) shows that the content of phosphate in the soil with the addition of NPK fertilizer is $0.48 \%$, biofertilizer is $0.41 \%$ and garden soil media is $0.31 \%$.

The dry weight of mustard plants in this study is indicated by weighing the total dry weight of the harvested crops (roots, stems and leaves). The results of the measurement of the dry weight of plants can be seen in Figure 7. Based on the one-way ANOVA test, biofertilizer has an effect on the dry weight of the plant. This is indicated by the value of $p$ value $(P<0.05)$ for dry weight is 0.002 . Then proceed with Tukey test to know which treatment has a significant influence on the treatments that have been done. The average result of dry weight measurement can be seen in Table 5 .

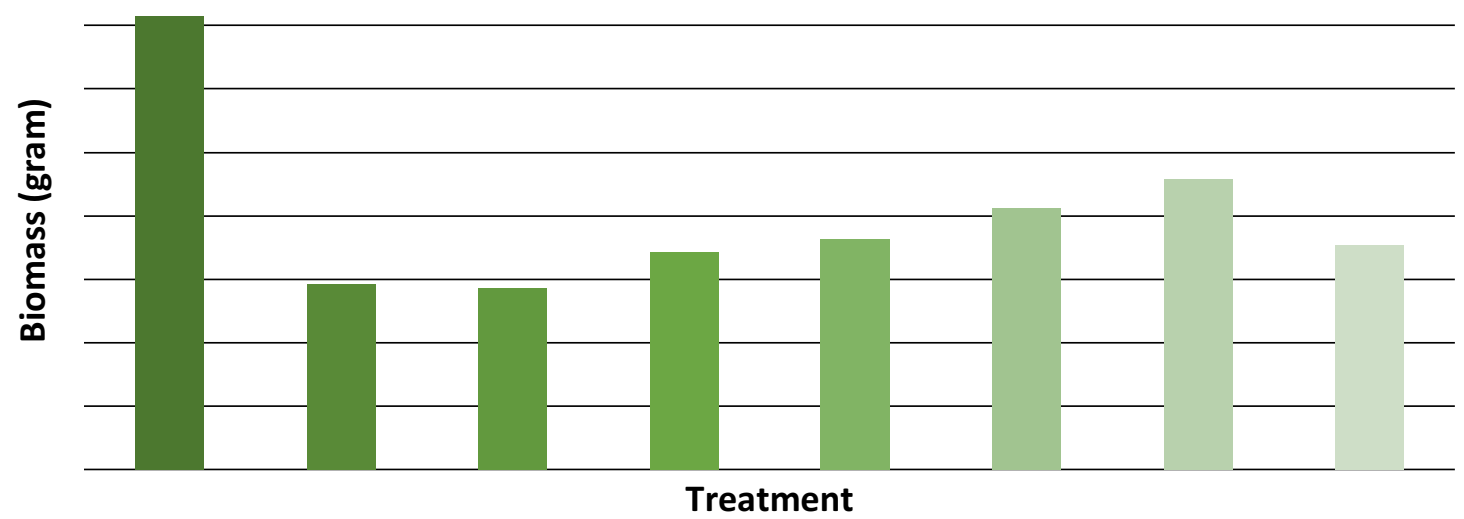

Figure 7. Result of Biomass 
Table 5. Biomass at Harvest Time

\begin{tabular}{ll}
\hline \multicolumn{1}{c}{ Treatment } & Dry weight (gram) \\
\hline Positive Control & $3,573^{\mathrm{a}}$ \\
Bacillus Candida & $2,290^{\mathrm{ab}}$ \\
Azotobacter Candida & $2,060^{\mathrm{b}}$ \\
Candida & $1,810^{\mathrm{b}}$ \\
Bacillus & $1,713^{\mathrm{b}}$ \\
Azotobacter Bacillus Candida & $1,766^{\mathrm{b}}$ \\
Azotobacter & $1,463^{\mathrm{b}}$ \\
Negative Control & $1,433^{\mathrm{b}}$ \\
\hline
\end{tabular}

*Figures followed by different letters show significant differences based on the Tukey test at the $95 \%$ confidence level $(\alpha=0.05)$.

Table 5 shows that treatment of Candida Bacillus consortium has the highest value on the dry weight parameters when compared with other biofertilizer treatment and not significantly different from the positive control treatment with the addition of NPK. This is because Bacillus has the potential as a phosphate solubilizer by releasing a number of organic acids and Candida has the potential to decompose organic matter in the soil.

Dry weight is also associated with carbon compounds that build plant organs. This correlates with the content of $C$ in soil. The result of the research is in accordance with the amount of soil $\mathrm{C}$ content that indicating the content of Carbon element on soil with the addition of NPK fertilizer is $2.05 \%$, the addition of biofertilizer is $1,98 \%$ and the garden soil is $1,62 \%$.

\section{Conclusions}

The results showed that all combination of yeast and bacteria as biofertilizer effect on mustard growth when compared with the treatment without biofertilizer. Candida and Bacillus consortium has the highest value of $13,6 \mathrm{~cm}$ at plant height. The Azotobacter Candida consortium on the parameters of the leaf area and number of leaves showed the highest yields with values of $20.3 \mathrm{~cm}$ and 5.3, respectively, and the Azotobacter Bacillus Candida consortium showed the highest value of $5.0 \mathrm{~cm}$ on the root length parameter. The Bacillus Candida consortium showed the highest value of 2.29 grams in dry weight.

\section{Acknowledgment}

This work was conducted as part of "Superior and Commercial Biofertilizer of Marine Yeast and Bacteria". This research was supported by grants from Pemula Research 2017 awarded by ITS local fund 2017.

\section{References}

Agamy, R., Hashem, M. \& Alamri, S. 2013. Effect Of Soil Amendment With Yeasts As BioFertilizers On The Growth And Productivity of Sugar Beet. African Journal of Agricultural Research, 8(1).

Ali,S.S \& Vidhale, N.N. 2013. Bacterial Siderophore and their Application: A review. Int.J.Curr.Microbiol.App.Sci, 2(12):303-312. 
Amprayn, K.O., Rose, M.T., Kecskes, M., Pereg, L., Nguyen, H.T. \& Kennedy, I.R. 2012. Plant Growth Promoting Characteristics of Soil Yeast (Candida tropicalis HY) and its Effectiveness for Promoting Rice Growth. Journal Of Applied Soil Ecology, 61: 295- 299.

Anubrata, P. \& Rajendra,D. 2014. Isolation, Characterization, Production of Biofertilizer, and Its Effect on Vegetable Plants with and without Carrier Materials. International Journal of Current Research, 6:7986-7995

Brock, T.D. \& Madigan, M.T.1991. Biology of Microorganisms. Sixth ed. Prentice Hall International, Inc

Cavalier-Smith, T. 1998. A Revised Six-Kingdom System Of Life. Biological Reviews, 73:20366.

Devi,M., Sharma,H.K., Rana, K. \& Mehta,D.K. 2017. Studies on Flower Biology and Pollination in Mustard (Brassica juncea L.). International Journal of Science and Nature, 8(1):35-39.

Duraisam,R. Salelgn,K. \& Berekete, A.K. 2017. Production of Beet Sugar and Bio-ethanol from Sugar beet and it Bagasse: A Review. International Journal of Engineering Trends and Technology (IJETT). 43(4) : 222-233.

Fleet G.H. 1992. Spoilage Yeasts. Critical Reviews in Biotechnology, 12(2):1-20.

Lucy, M., Reed, E. \& Glick, B.R. 2004. Application of Free Living Plant Growth-Promoting Rhizobacteria. Antonie Van Leeuwenhoek, 86: 1-25.

Maheswar, N. U. \& Sathiyavani, G. 2012. Solubilization of Phosphate by Bacillus Sps, from Groundnut Rhizosphere. Journal of Chemical and Pharmaceutical Research, 4(8):40074011

Masso, C., Ochieng, J.R.A. \& Vanlauwe, B. 2015. Worldwide Contrast in Application of BioFertilizers for Sustainable Agriculture: Lessons for Sub-Saharan Africa. Journal of Biology, Agriculture and Healthcare, 5 (12).

New,M.T., Yu,S.S. \& Latt, Z.K. 2013. Study on Phosphate Solubilization of Salt Tolerant Soil Yeast Isolates and Effects on Maize Germination and Growth. International Journal of Advances in Applied Sciences, 2(3):157-164.

Ng'etich, Niyokuri, O.K.A.N., Rono, J.J., Fashaho, A. \& Ogweno J.O. 2013. Effect of Different Rates of Nitrogen Fertilizer on the Growth and Yield of Zucchini (Cucurbita pepo cV. Diamant L.) Hybrid F1 in Rwandan High Altitude Zone. International Journal of Agriculture and Crop Sciences. 5 (1) : 54-62.

Noel, D.D., Nafan,D., Souleymane, S., Jean-Luc, M.A., Jesus, F.I. \& Lamine, B.M. 2016. Combination of Rizhobacteria and Foliar Bio-Fertilizer Accelerating Maize and Soybean Crop Plants Growth Process in Arid Soil. Academia Journal of Agricultural Research, 4(7):446-456.

Park, Y., Mun, B., Kang, S., Hussain, A., Shahzad, R., Seo, C., Kim, A., Lee, S., Oh, K.Y., Lee,D.Y., Lee, I. \& Yun, B. 2017. Bacillus aryabhattai SRB02 Tolerates Oxidative and Nitrosative Stress and Promotes the Growth of Soybean by Modulating the Production of Phytohormones. Plos One, 12(3).

Paszt, L.S., Derkowska, E., Trzciński, P., Przybył, M. \& Weszczak, K. 2015. Influence of Biofertilizers on Plant Growth and Rhizosphere Microbiology of Greenhouse-Grown Strawberry Cultivars. Acta Sci. Pol. Hortorum Cultus, 14(6):83-96.

Paulton, R.J.L. 1991. The Bacterial Growth Curve. J Biol Educ, 25:92-93.

Plaster, E. J. 2003. Soil Science and Mangement. Delmar Learning Inc. 4th ed United States.

Smith, S.E. \& Read, D.J. 2008. Mycorrhizal Symbiosis, 3rd ed. New York, London, Burlington, San Diego: Elsevier and Academic. 
Vessey, J.K. 2003. Plant Growth Promoting Rhizobacteria as Biofertilizers. Plant Soil, 255: 57186.

Wang, X., Pan, Q., Chen, F., Yan, X. \& Liao, H. 2011. Effects of Co-inoculation with Arbuscular Mycorrhizal Fungi and Rhizobia on Soybean Growth as Related to Root Architecture and Availability of $\mathrm{N}$ and P. Mycorrhiza. 21:173-181.

Wani, S.A., Subhash, C. \& Tahir, A. 2013. Potential Use Of Azotobacter Chroococcum in Crop Production. Current Agriculture Research Journal, 1(1).

Xiao, C., Chi, R., Pan, X., Liu, F. \& He, J. 2013. Rock Phosphate Solubilization by Four Yeast Strains. Annals of Microbiology, 63:173-178

\section{To cite this article:}

Alami, N.H., Ayu, S.A.T., Kuswytasari, N.D., Zulaika, E \& Shovitri, M. 2017. Effect of Yeast Based Biofertilizer combined with bacteria on Mustard Plant Growth. International Journal of Applied Biology. $1(2): 46-57$. 